\title{
Evaluation of groundwater quality in a rural community in North Central of Nigeria
}

\section{Adebayo Olatunbosun Sojobi}

\section{Environmental Monitoring and Assessment}

An International Journal Devoted to Progress in the Use of Monitoring Data in Assessing Environmental Risks to Man and the Environment

\section{ISSN 0167-6369}

Volume 188

Number 3

Environ Monit Assess (2016) 188:1-17 DOI 10.1007/s10661-016-5149-y

\section{ENVIRONMENTAL MONITORING AND ASSESSMENT}

An International Journal devoted to progress in the use of monitoring data in assessing environmental risks to Man and the environment. ISSN $0167-6369$
CODEN EMASDH

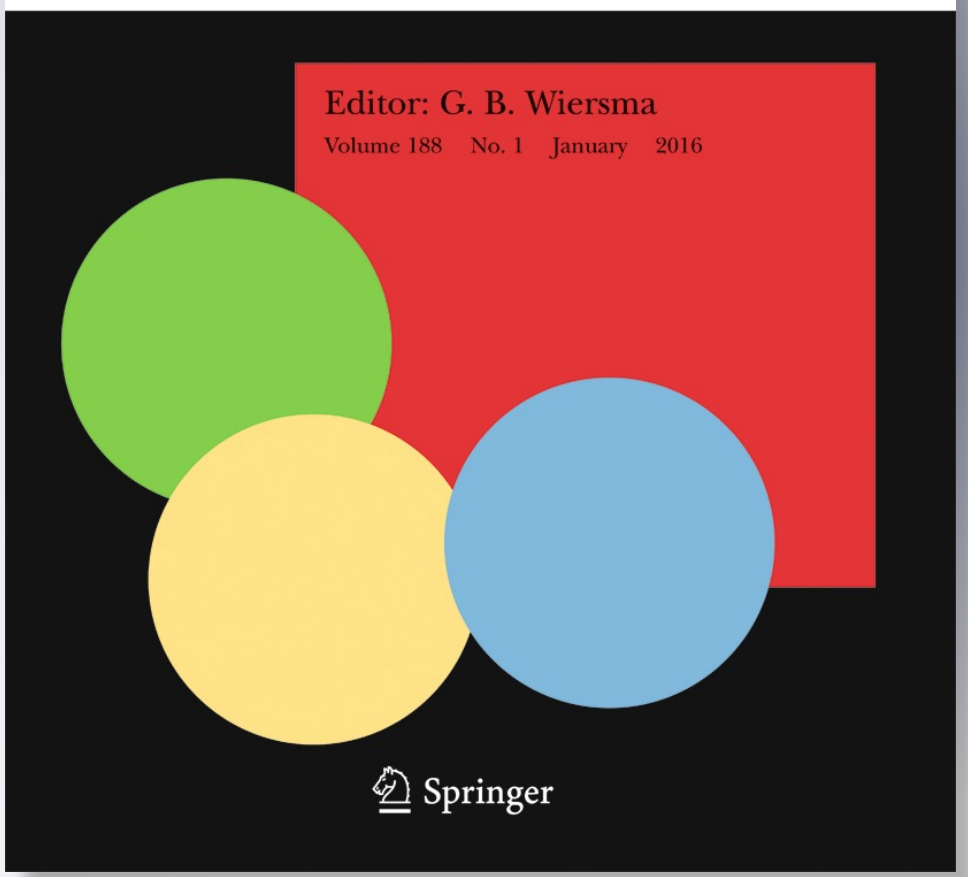

Springer 
Your article is protected by copyright and all rights are held exclusively by Springer International Publishing Switzerland. This eoffprint is for personal use only and shall not be self-archived in electronic repositories. If you wish to self-archive your article, please use the accepted manuscript version for posting on your own website. You may further deposit the accepted manuscript version in any repository, provided it is only made publicly available 12 months after official publication or later and provided acknowledgement is given to the original source of publication and a link is inserted to the published article on Springer's website. The link must be accompanied by the following text: "The final publication is available at link.springer.com". 


\title{
Evaluation of groundwater quality in a rural community in North Central of Nigeria
}

\author{
Adebayo Olatunbosun Sojobi
}

Received: 8 April 2015 / Accepted: 1 February 2016

(C) Springer International Publishing Switzerland 2016

\begin{abstract}
Evaluation of water quality of nine boreholes and three open hand-dug wells in a rural community in North Central Nigeria revealed relative abundance of cations $\mathrm{Na}>\mathrm{k}>\mathrm{Ca}>\mathrm{Mg}>\mathrm{Zn}>\mathrm{Pb}$ and anions $C \Gamma>$ $\mathrm{PO}_{4}^{2-}>\mathrm{SO}_{4}^{2-}>\mathrm{NO}_{3}^{-}$in the boreholes and cations $\mathrm{Ca}>\mathrm{Na}>\mathrm{K}>\mathrm{Mg}>\mathrm{Pb}$ and anions $\mathrm{NO}_{3}^{-}>\mathrm{PO}_{4}^{2-}>\mathrm{SO}_{4}^{2-}$ $>\mathrm{Cl}$ in the wells. The major contaminants exceeding $\mathrm{SON}$ and WHO permissible limits were $\mathrm{NO}_{3}^{-}, \mathrm{Mg}, \mathrm{TH}$, $\mathrm{pH}$ and $\mathrm{Mg}, \mathrm{Pb}, \mathrm{TH}, \mathrm{pH}$ and $\mathrm{DO}$ in the wells and boreholes, respectively. They are attributable to anthropogenic sources such as domestic waste water and poor waste disposal and natural sources such as mineral dissolution from clayey aquifer which made the acidic groundwater unsuitable for consumption unless they are appropriately treated. Correlation studies revealed existence of three major mineral groups in the aquifer $\mathrm{Ca}-\mathrm{Fe}$ group, $\mathrm{Na}-\mathrm{Mg}$ group, $\mathrm{Zn}-\mathrm{K}$ group, as well as a minor group $\mathrm{Pb}$-group, and they determine the chemical composition of the groundwater and the ionic exchange between the groundwater and mineral-bearing clayey aquifer. In order to curb microbial contamination by Enterobacter aerogenes and Escherichia coli, it is recommended that proper latrines and drainages be provided while domesticated animals should be restricted from boreholes and well. Further, treatment with water guard and pur purifier is recommended.
\end{abstract}

\footnotetext{
A. O. Sojobi $(\bowtie)$

Department of Civil Engineering, Landmark University, PMB 1001, Omu Aran, Kwara State, Nigeria

e-mail: adebayosojobi@gmail.com
}

Keywords Water quality · Borehole · Well · Groundwater $\cdot$ Correlation

\section{Introduction}

Water is essential for supporting livelihoods, safeguarding public health, providing food security, ensuring environmental sustainability, promoting industrial and economic development, improving living standards, and achieving sustainable development (Dinka et al., 2015; Falkenmark, 2015; Gwenzi et al., 2015; Huang et al., 2014; Kumar et al., 2015; Mayzelle et al., 2015; Sobowale et al., 2015). It is estimated that about 3.4 billion people in developing countries are highly vulnerable to water insecurity which developed countries have overcomed through massive technological, management investments as reported by Vorosmarty et al. (2010) as well as infrastructural investments.

According to Estache (2008) and Tortajada (2002), efficient delivery of improved water services depends not only on the provision of infrastructure but also on well-planned, properly maintained and operated infrastructure, effective regulations, responsive and flexible institutions, efficient public and private operators, increased accountability, appropriate governance structures, sustainable financing, and effective public participation.

The inability of governments at federal, state, and local government levels to meet the basic water needs of their populations have resulted in economic, social, environmental, and health costs. The attendant results 
are poor water access in urban, peri-urban, and rural areas, high rate of premature mortality and morbidity, environmental pollution, consumption of contaminated, over-exploited and polluted groundwater, and surface water resources and decreased household income and productivity (Sojobi et al., 2014; Tortajada, 2002). Oyegoke et al. (2012) attributed the water demandsupply gap in Nigeria to the use of ad hoc isolated prescription, unsustainable initiatives, paucity of innovative solutions in planning and development, population explosion, faulty and poor maintenance culture, frequent power outage, poor planning, and lack of political will.

In order to close the infrastructural deficit gap, SubSahara Africa (SSA) needs approximately \$93 billion (World Bank, 2011). Developing countries such as Nigeria would need to invest $\$ 1.2-1.5$ billion every year to provide necessary services such as safe drinking water, electricity, and good roads (Fay et al., 2010) while Estache (2008) recommended that not less than $8 \%$ of their annual GDP must be expended on infrastructure.

It has been found that the problem of water quality in developing countries, Nigeria inclusive, is also a problem of water crises. Water crises in many parts of the world are caused by deficient water governance characterized by mismanagement, corruption, lack of appropriate institutions, bureaucracy, and lack of investment (Biswas and Tortajada, 2010; Gutierrez et al., 2013; UNESCO, 2009). These crises can be categorized as economic water crises, political water crises, institutional water crises, technological, operational, and water quality crises.

In order to address these crises, multi-focussed solutions embedding innovative financing, sustainable (community) water governance, citizen participation, post-construction guidance and support, institutional reforms, transparency and accountability, and poverty alleviation are required (Baguma et al., 2012; Biswas and Tortajada, 2010; Gutierrez et al., 2013; Sato, 2014; Taher et al., 2012; Tortajada, 2002; Tortajada, 2010; Wiek and Larson, 2012). In addition, it is high time water professionals realized that the heterogeneous nature of water problems which varies locally, regionally, seasonally, and yearly cannot be solved by them alone since they are interlinked with other development and social sectors (Biswas, 2008).

For rural people, the major sources of drinking water are groundwater from boreholes, shallow wells, and springs (Dwairo et al., 2006; NBS, 2010) and are often consumed without treatment which poses a threat to their health (Abatneh et al., 2014). Groundwater alone serves $25 \%$ of human population in arid and semi-arid regions (Jackson et al., 2001; Oki and Kanae, 2006).

Groundwater quality is affected and determined by anthropogenic and natural processes which include hydrogeological condition of the aquifer, geochemical reactions, lithology, soil-rock water interactions, saline water intrusion, tidal fluctuation, agricultural activities, unplanned rural and urban development, industrialization, land use changes, improper solid and liquid waste disposal and management, groundwater pumping, proximity to and leaching from potential sinks such as poorly designed landfills, septic tanks, and drainage system, and quality of wells and boreholes (Akhtar et al., 2014; Al-ahmadi and El-Fiky, 2009; Huang et al., 2014; Kumar et al., 2015; Oni and Hassan, 2013; Oyelami et al., 2013; Porowska, 2014; Rao, 2014; Srinivas et al., 2013; Vasanthaviger et al., 2013; Wanke et al., 2015). Contaminants in groundwater vary from one location to another and include different kinds of microbes, organic and inorganic substances, anions, cations, heavy metals, and minerals as shown in Table 1. Water-related diseases associated with poor quality and contaminated water are listed in Table 2.

\section{Materials and methods}

The study area is Omu Aran located in Irepodun Local Government Area of Kwara State in the North Central region of Nigeria. Omu Aran is located on latitude $8.9^{0} \mathrm{~N}$ and longitude 5.60 $\mathrm{E}$ while Kwara State is located on latitude $8^{0} 30^{\prime} \mathrm{N}$ and longitude $5^{0} 0^{\prime} \mathrm{E}$ (Sojobi et al., 2014). The vegetation is predominantly guinea savannah as shown in Fig. 1 while the climate is tropical maritime monsoon with about 8 months of heavy rainfall. The average annual rainfall, average annual maximum temperature, and annual mean relative humidity are $1262.8 \mathrm{~mm}, 35.8^{\circ} \mathrm{C}$, and $82.2 \%$, respectively (KWADP 2012).

Basic amenities such as piped-borne water and hospitals are grossly inadequate. Based on statistics provided by National Bureau of Statistics (NBS), $88.68 \%$ of the population in Kwara State are poor, which is one of the highest in Nigeria and indicates extreme level of poverty as reported in a joint-report by NBS/UNICEF/ UNFPA Joint (2011). Furthermore, $41.2 \%$ of the households in Irepodun LGA shown in Fig. 2 rely on borehole 


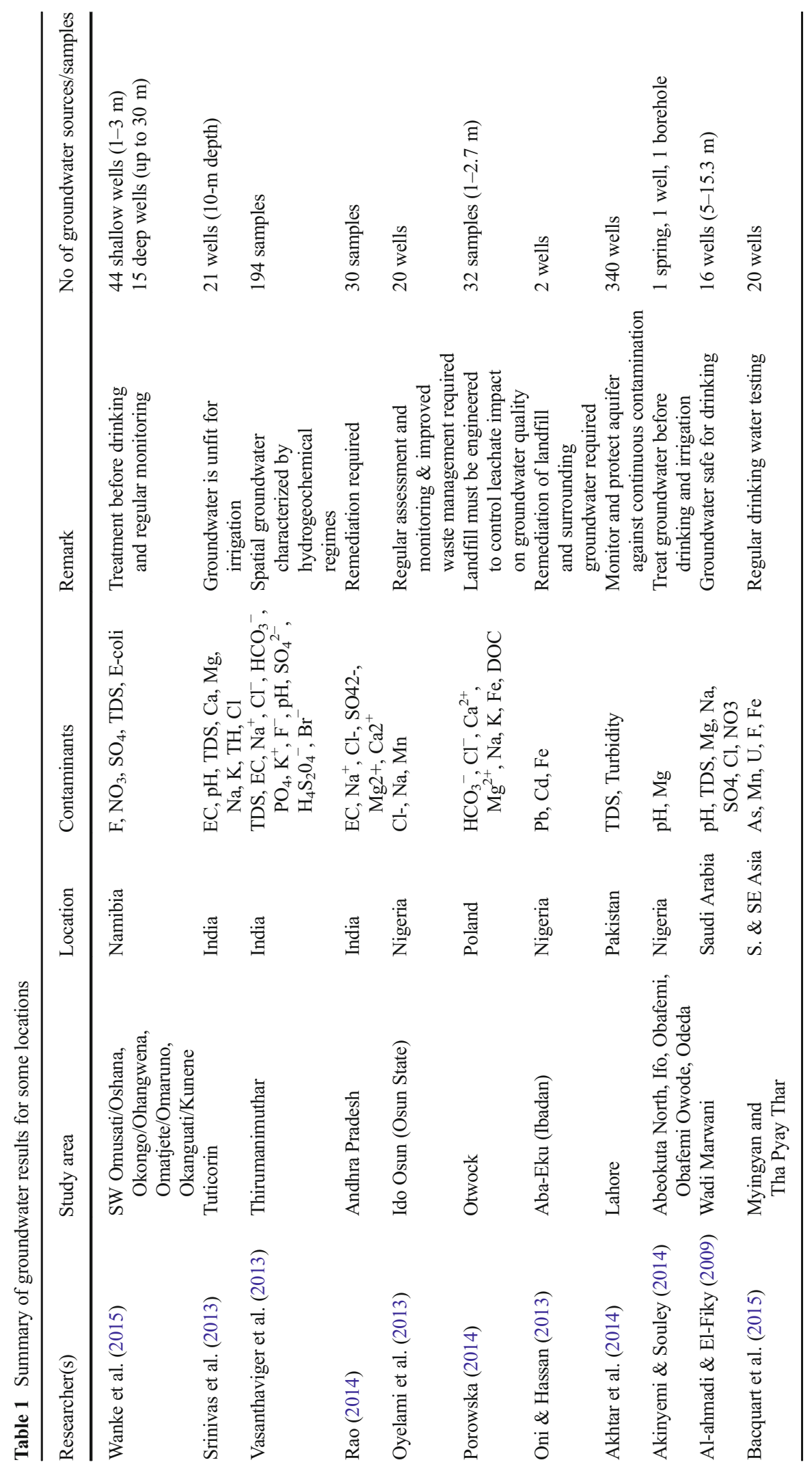


Table 2 Water-related diseases caused by some contaminants in water

\begin{tabular}{|c|c|c|c|}
\hline Parameters & Causes & Diseases & Source \\
\hline $\mathrm{Ph}$ & & Gastrointestinal irritation & Khan et al. (2013) \\
\hline $\mathrm{SO}_{4}$ & Fertilizer contamination & Laxative action & WHO (1996) \\
\hline $\mathrm{NO}_{3}$ and $\mathrm{NO}_{2}$ & $\begin{array}{l}\text { Over-application of fertilizer, } \\
\text { sewage disposal, manure } \\
\text { application, wastewater, } \\
\text { leakage, landfill leachate, } \\
\text { municipal runoff }\end{array}$ & Methemoglobinemia in infants & $\begin{array}{l}\text { Khan et al. (2013), } \\
\text { Saeedi et al. (2012) }\end{array}$ \\
\hline \multirow[t]{5}{*}{$\mathrm{Pb}$} & & $\begin{array}{l}\text { Subencephalopathic, neurological, } \\
\text { and behavioral effects }\end{array}$ & WHO (1993) \\
\hline & Acute toxicity & $\begin{array}{l}\text { Tiredness, lassitude, abdominal discomfort, } \\
\text { irritability, anemia and behavioral changes }\end{array}$ & Gerlach et al. (2002) \\
\hline & High levels of $\mathrm{Pb}$ in children & $\begin{array}{l}\text { Convulsion, neurological damage, organ } \\
\text { failure, coma, and death }\end{array}$ & Khan et al. (2013) \\
\hline & Moderate levels of $\mathrm{Pb}$ & $\begin{array}{l}\text { Hearing loss, inhibit growth, } \\
\text { learning disabilities }\end{array}$ & Khan et al. (2013) \\
\hline & Accumulative toxicity & $\begin{array}{l}\text { Lead poisoning, harm stomach, intestine, } \\
\text { and stomach }\end{array}$ & Shu et al. (2011) \\
\hline $\mathrm{Cd}$ & High toxicity & $\begin{array}{l}\text { Kidney disease, anaemia, chronic poisoning } \\
\text { leading to albuminuria, and osteomalacia }\end{array}$ & Shu et al. (2011) \\
\hline $\mathrm{Hg}$ & Accumulative toxicity & $\begin{array}{l}\text { Harm nervous system, heart, kidney, } \\
\text { intestines, and stomach }\end{array}$ & Shu et al. (2011) \\
\hline $\mathrm{Cu}$ & & $\begin{array}{l}\text { Harm liver, cardiovascular disease and } \\
\text { coronary heart disease }\end{array}$ & Shu et al. (2011) \\
\hline $\mathrm{Mn}$ & & $\begin{array}{l}\text { Cartilage growth disturbances when deficit, } \\
\text { arthroncus and soft bone, Mn-poisoning, } \\
\text { manganese-related madness, } \\
\text { and pneumosclerosis }\end{array}$ & Shu et al. (2011) \\
\hline $\mathrm{Zn}$ & & $\begin{array}{l}\text { Retard intelligence development and } \\
\text { cardiosvascular, sickness, vomiting }\end{array}$ & Shu et al. (2011) \\
\hline $\mathrm{Cr}^{6+}$ & & Contact dermatitis and respiratory cancer & Shu et al. (2011) \\
\hline As & High concentration & $\begin{array}{l}\text { Sickness, stomach ache, diarrhea, } \\
\text { inflammatory bowel disease, edema or } \\
\text { even death, hernolytic anemia, jaundice, } \\
\text { red blood cell disruption }\end{array}$ & Shu et al. (2011) \\
\hline $\mathrm{Ca}$ & Deficiency & Osteoporosis and hypertension & Yang and Chiu (1999) \\
\hline \multirow[t]{2}{*}{$\mathrm{Mg}$} & Deficiency & $\begin{array}{l}\text { Vasocontrictions, hypertension, cardiac arrhythmia, } \\
\text { atherosclerotic vascular disease, acute myocardial } \\
\text { infarction, preeclampsia in pregnant women, } \\
\text { diabetes miletus, osteoporosis, }\end{array}$ & $\begin{array}{l}\text { Melles and Kiss (1992); } \\
\text { Yang et al. (2002) }\end{array}$ \\
\hline & Water low in $\mathrm{Mg}$ & $\begin{array}{l}\text { Increased morbidity and mortality, cardiovascular } \\
\text { disease, higher risk for motor neuronal disease, } \\
\text { pregnancy disorders, preeclampsia, fracture } \\
\text { in children, neurodegenerative disease, } \\
\text { preterm birth, low weight birth, cancer }\end{array}$ & Verd et al. (1992) \\
\hline
\end{tabular}

while $31.2 \%$ rely on wells as their major sources of water for drinking and cooking (NBS, 2010).

Water samples for this study were collected between August 4 and September 11, 2014 from nine (9) boreholes (wells with electric pump) and three (3) hand-dug wells (artificial pumpless wells). Samples were collected at each site weekly with the aid of new high-density PET screw-capped containers of 1.5-L capacity. Water from the boreholes was allowed to run for $5 \mathrm{~min}$, immediately followed by reduction in the water flow in order to avoid splashing during filling of bottles. Gases were removed from the bottles by filling and emptying the bottles before the collection of actual water samples. For hand-dug wells, the water was given a little disturbance with a drawing bucket for about five consecutive times to allow for proper mixing of the well water before 


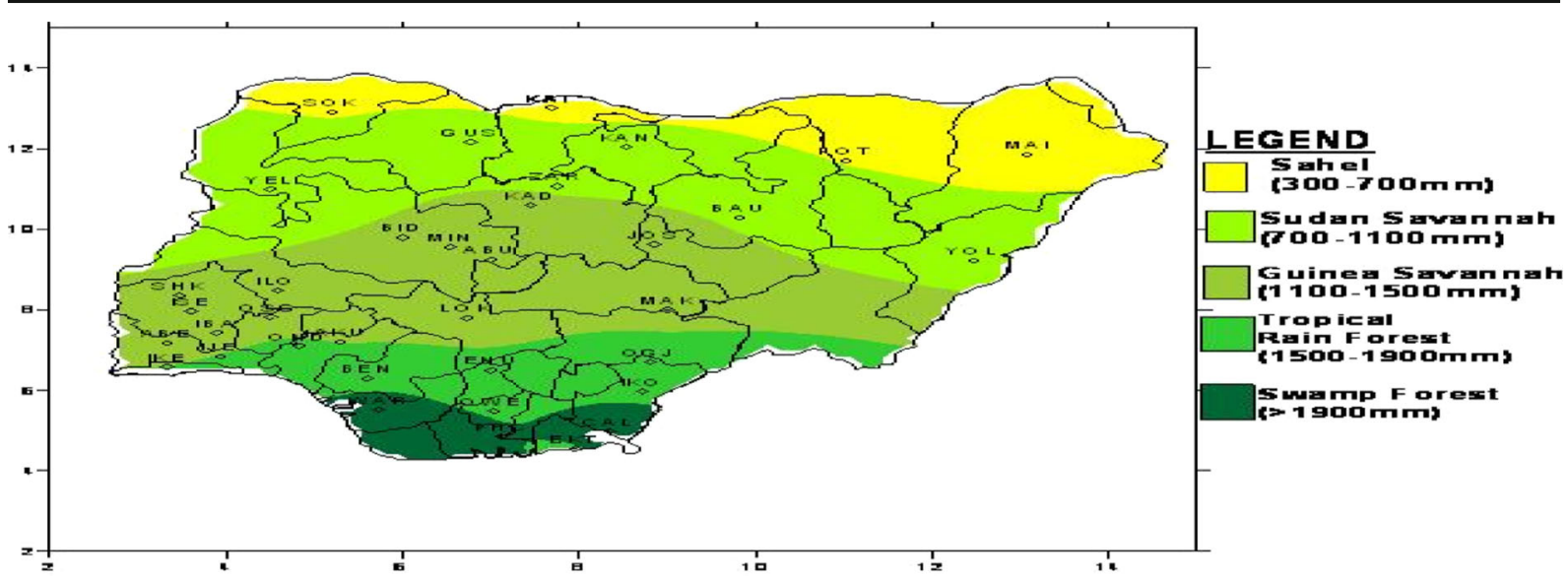

Fig. 1 Map of Nigeria showing the vegetation zones

the actual samples were drawn out. In each case, the PET bottles and stoppers were thoroughly washed with distilled water for three times and thrice with the water to be sampled before actual sample collection (Dahunsi et al., 2014).

At each site, one bottle was filled with water, having no added acid while the other bottle was filled with the water from the same point and acidified by adding a few drops of $5 \% \mathrm{HNO}_{3}$ to stop microbial proliferation. At the same time, samples for microbial analysis were collected using autoclave-sterilized sample bottles from the same locations (Dahunsi et al., 2014). The water samples were preserved in a refrigerator at $40^{\circ} \mathrm{C}$ to keep the water content intact before they were transported within 3 hours in an ice cooler at $4{ }^{\circ} \mathrm{C}$ to Central Research Laboratory of the Federal University of Technology, Akure, in Ondo State, Nigeria, for physical, chemical, and microbiological analyses.
Physical parameters including $\mathrm{pH}$ (HI 9024-C, Hanna Instruments, Smithfield, RI, USA), temperature (HI 98517, Hanna Instr.), salinity (HI 19311, Hanna Instr.), electrical conductivity (HI 2315, Hanna Instr.), and total dissolved solids (TDS) (VSI 22, VSI Electronics Private Limited, Punjab, India) were analyzed in situ using the aforementioned hand digital meters. Dissolved oxygen was analyzed using the azide modification of Winkler's method as described in APHA (1992). Chloride content was determined by titration according to the method described in (Dahunsi et al., 2014). Determination of the major anions was carried out using ultraviolet (UV) spectrophotometer screening method (APHA, 2012) using a UV spectrophotometer (DR 2800, HACH, Washington, USA) (Dahunsi et al., 2014; Khan et al., 2013; Ayandiran et al., 2014). To maintain reliability and reproducibility in the analyses, the blank, standard, and pre-analyzed were done after every 10 samples

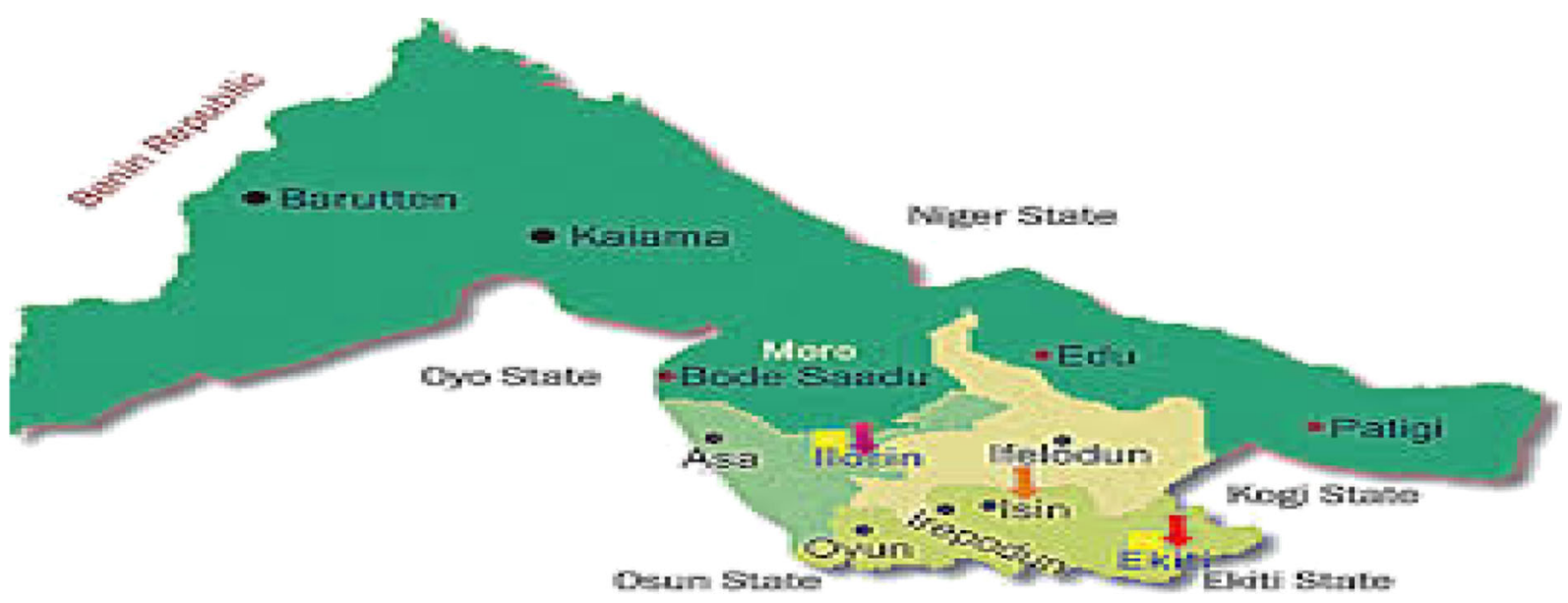

Fig. 2 Showing location of Irepodun LGA in Kwara State and the surrounding States 
(Dahunsi et al., 2014). Standard methods were used to determine the total viable and coliform bacteria counts as the most probable number (MPN) in water samples as described in APHA (2012). Metal analyses were done with the aid of atomic absorption spectrophotometer (AAS) (Sens AA 3000, GBC, Australia) using the method in APHA (2012). For each water parameter, the average values obtained in the baseline for boreholes and well water samples were recorded.

\section{Results and discussion}

Physico-chemical properties

The results displayed in Table 3 showed that the relative abundance of the major cations and anions in the boreholes were $\mathrm{Na}>\mathrm{k}>\mathrm{Ca}>\mathrm{Mg}>\mathrm{Zn}>\mathrm{Pb}$ and $\mathrm{Cl}>\mathrm{PO}_{4}^{2-}$ $>\mathrm{SO}_{4}^{2-}>\mathrm{NO}_{3}^{-}$, respectively. For the wells, the relative abundance of the major cations and anions were $\mathrm{Ca}>\mathrm{Na}>\mathrm{K}>\mathrm{Mg}>\mathrm{Pb}$ and $\mathrm{NO}_{3}^{-}>\mathrm{PO}_{4}^{2-}>\mathrm{SO}_{4}^{2-}>\mathrm{Cl}$, respectively. Our findings were different from the relative cations and anions obtained by Devic et al. (2014) which were $\mathrm{Ca}>\mathrm{Mg}>\mathrm{Na}>\mathrm{K}$ and $\mathrm{HCO}_{3}{ }^{-}, \mathrm{SO}_{4}{ }^{2-}>\mathrm{Cl}$ $>\mathrm{NO}_{3}{ }^{-}$, respectively.

Based on Freeze and Cherry (1979) classification, the groundwater in the study area can be described as freshwater (TDS $<1 \mathrm{gL}^{-1}$ ) since both the boreholes and wells have mean TDS values of 0.23 and $0.42 \mathrm{mg} / 1$ values. The freshwater nature of the groundwater was also corroborated by their mean EC values of 300 and $530 \mathrm{~ms} / \mathrm{cm}$, respectively, which was $<1500 \mu \mathrm{s} / \mathrm{cm}$ for freshwater according to Mondal et al. (2008). These results also indicate that borehole water was clearer than well water and contained less dissolved substances even though they have the same mean turbidity value of 0.01 NTU. Their apparent low turbidity $(<0.01)$, which is very good (Akhtar et al., 2014), could be very deceptive as a clean source of drinking water that does not require treatment. However, their $\mathrm{pH}(<6.5)$ revealed that they were acidic according to Akhtar et al. (2014) which could lead to gastrointestinal irritation (Khan et al., 2013) and require alkaline treatment in order to improve their $\mathrm{pH}$ to the acceptable range of $6.5-8.5$ as shown in Table 4 (SON, 2007; WHO, 2006). Sojobi et al. (2014) attributed their acidic nature to the geological formation of the area, and their average TDS was below the SON and WHO permissible limits of $500 \mathrm{mg} /$ 1. Similarly, Akinyemi and Souley (2014) found $\mathrm{pH}$ to a problem in groundwater resources in Ogun State and recommended treatment before drinking.

Further, the boreholes and wells with mean total hardness $(\mathrm{TH})$ values of 178.67 and $210 \mathrm{mg} / \mathrm{l}$ could be classified as moderately hard (150-200 mg/l) and hard (200-300 mg/l), respectively, based on classification of Abd El Salam and Abu-Zuid (2015) and were higher than the SON permissible limit of $150 \mathrm{mg} / \mathrm{l}$ required for drinking water. Nonetheless, the TH of the boreholes was highly variable with a higher standard deviation (SD) of 122.85 compared to that of wells of 4.08. Hard water promotes deposition of metals in water pipelines, precipitation of the metals during treatments which has the potential to reduce the efficiency of water treatment. In addition, hard water causes more expense of soap when used for laundry purposes owing to its lowfoaming ability. Results of correlation studies revealed that the major ions contributing to the hardness were $\mathrm{Na}$, $\mathrm{Ni}, \mathrm{K}$, and $\mathrm{Mg}$.

The mean value of DO $(6.5 \mathrm{mg} / \mathrm{l})$ for well was within the SON permissible limit of $7.5 \mathrm{mg} / \mathrm{l}$ while that of borehole $(7.91 \mathrm{mg} / \mathrm{l})$ exceeded it, even though both of them were above WHO permissible limit of $4 \mathrm{mg} / \mathrm{l}$. The level of their DO could be traced to their $\mathrm{BOD}_{5}$. Borehole had higher mean $\mathrm{BOD}_{5}$ of $3.4 \mathrm{mg} / \mathrm{l}$ compared to well with mean value of $2.60 \mathrm{mg} / \mathrm{l}$. Their low $\mathrm{BOD}_{5}$ which was below SON permissible limit of $6 \mathrm{mg} / \mathrm{l}$ indicated low organic pollution, with boreholes having a higher organic pollution. The higher organic pollution of the borehole could be linked to poor construction of the boreholes and their location to possible sources of pollution such as domestic wastewater effluents and sewage tanks. This was also buttressed by the fact that borehole had higher mean Escherichia coli level of $658.33 \mathrm{cfu} / \mathrm{ml}$ compared to well with mean value of $570 \mathrm{cfu} / \mathrm{ml}$.

Besides, the boreholes were also found to have mean yeast concentration of $403.67 \mathrm{cfu} / \mathrm{ml}$ which was also higher than $160 \mathrm{cfu} / \mathrm{ml}$ obtained for well. In contrast, well had total coliform (TC) of 1100 which was greater compared to the mean concentration of 803.33 obtained for the boreholes.

The mean sodium ( $\mathrm{Na}$ ) concentrations of the boreholes $(8.67 \mathrm{mg} / \mathrm{l})$ and wells $(12.8 \mathrm{mg} / \mathrm{l})$ were below the SON and WHO permissible limit of $200 \mathrm{mg} / \mathrm{l}$ but were lower compared to their corresponding mean chloride concentrations of 69.42 and $4.5 \mathrm{mg} / \mathrm{l}$. This suggests preponderance of halite sources as a major source of chloride ion for the boreholes. Similarly, the chloride 
Table 3 Statistics of physico-chemical analyses of the groundwater resources of the study area

\begin{tabular}{|c|c|c|c|c|c|c|c|c|c|c|}
\hline \multirow[t]{2}{*}{ Parameters } & \multicolumn{5}{|l|}{ Borehole } & \multicolumn{5}{|l|}{ Wells } \\
\hline & No. data & Max & Min & Avg & $\mathrm{SD}$ & No. data & Max & Min & Avg & $\mathrm{SD}$ \\
\hline Turb (NTU) & 54 & 0.01 & 0.001 & 0.01 & 0.00 & 18 & 0.03 & 0.01 & 0.01 & 0.01 \\
\hline $\mathrm{EC}(\mathrm{ms} / \mathrm{cm}) \times 10^{2}$ & 54 & 3.4 & 2.75 & 3.00 & 0.23 & 18 & 5.35 & 5.25 & 5.30 & 4.08 \\
\hline $\mathrm{pH}$ & 54 & 5.75 & 5.68 & 5.72 & 0.00 & 18 & 5.37 & 5.35 & 5.36 & 0.03 \\
\hline TS (mg/l) & 54 & 0.73 & 0.16 & 0.37 & 0.24 & 18 & 0.47 & 0.45 & 0.46 & 0.01 \\
\hline TDS (mg/l) & 54 & 0.34 & 0.15 & 0.23 & 0.07 & 18 & 0.43 & 0.41 & 0.42 & 0.01 \\
\hline $\mathrm{TH}(\mathrm{mg} / \mathrm{l})$ & 54 & 354 & 80 & 178.67 & 122.85 & 18 & 215 & 205 & 210 & 4.08 \\
\hline $\mathrm{DO}(\mathrm{mg} / \mathrm{l})$ & 54 & 8.10 & 7.95 & 7.91 & 0.11 & 18 & 6.52 & 6.48 & 6.5 & 0.02 \\
\hline $\mathrm{BOD}_{5}(\mathrm{mg} / \mathrm{l})$ & 54 & 3.60 & 3.10 & 3.40 & 0.16 & 18 & 2.65 & 2.55 & 2.60 & 0.04 \\
\hline $\mathrm{Cl}(\mathrm{mg} / \mathrm{l})$ & 54 & 123.50 & 41.00 & 69.42 & 72.06 & 18 & 4.60 & 3.50 & 4.5 & 0.08 \\
\hline $\mathrm{NO}_{3}(\mathrm{mg} / \mathrm{l})$ & 54 & 4.30 & 3.40 & 3.77 & 1.86 & 18 & 96.30 & 96.20 & 96.25 & 0.04 \\
\hline $\mathrm{SO}_{4}(\mathrm{mg} / \mathrm{l})$ & 54 & 6.10 & 5.20 & 5.60 & 0.31 & 18 & 5.55 & 5.45 & 5.5 & 0.04 \\
\hline $\mathrm{PO}_{4}(\mathrm{mg} / \mathrm{l})$ & 54 & 15.60 & 12.20 & 14.27 & 1.41 & 18 & 15.65 & 15.55 & 15.6 & 0.04 \\
\hline $\mathrm{Cd}(\mathrm{mg} / \mathrm{l})$ & 54 & ND & ND & ND & ND & 18 & $\mathrm{ND}$ & ND & ND & ND \\
\hline $\mathrm{Pb}(\mathrm{mg} / \mathrm{l})$ & 54 & 0.04 & 0.00 & 0.03 & 0.00 & 18 & 0.05 & 0.03 & 0.04 & 0.01 \\
\hline $\mathrm{Cr}(\mathrm{mg} / \mathrm{l})$ & 54 & ND & ND & ND & ND & 18 & $\mathrm{ND}$ & ND & ND & ND \\
\hline Ni (mg/l) & 54 & 0.01 & 0.00 & 0.00 & 0.01 & 18 & ND & ND & ND & ND \\
\hline $\mathrm{Zn}(\mathrm{mg} / \mathrm{l})$ & 54 & 0.29 & 0.02 & 0.11 & 0.11 & 18 & $\mathrm{ND}$ & ND & ND & ND \\
\hline $\mathrm{Fe}(\mathrm{mg} / \mathrm{l})$ & 54 & ND & ND & ND & ND & 18 & 0.01 & 0.01 & 0.01 & 0.00 \\
\hline $\mathrm{Na}(\mathrm{mg} / \mathrm{l})$ & 54 & 12.95 & 6.45 & 8.67 & 2.99 & 18 & 12.85 & 12.75 & 12.8 & 0.04 \\
\hline $\mathrm{K}(\mathrm{mg} / \mathrm{l})$ & 54 & 12.95 & 2.25 & 7.24 & 4.36 & 18 & 5.10 & 4.90 & 5 & 0.08 \\
\hline $\mathrm{Ca}(\mathrm{mg} / \mathrm{l})$ & 54 & 7.05 & 1.90 & 3.67 & 2.36 & 18 & 22 & 20 & 21.00 & 0.82 \\
\hline $\mathrm{Mg}(\mathrm{mg} / \mathrm{l})$ & 54 & 0.94 & 0.75 & 0.84 & 0.07 & 18 & 0.92 & 0.90 & 0.91 & 0.01 \\
\hline
\end{tabular}

Turb turbidity, EC electrical conductivity, Max maximum, Min minimum, Avg average, SD standard deviation

concentrations were below SON permissible limit of $250 \mathrm{mg} / \mathrm{l}$. The high SD $( \pm 72.06 \mathrm{mg} / \mathrm{l})$ of the chloride concentrations portrays the high variability of this halite sources within the area while the variability for the well is insignificant with SD value of 0.08 . Na causes scale formation and corrosion in boilers as mentioned by Todd (1980). Also, high Na suggests strong wateraquifer interaction related to either cation exchange or anthropogenic pollution from wastewater and septic tanks according to Wayland et al. (2003).

The mean concentrations of magnesium $(\mathrm{Mg})$ in both the boreholes $(0.75 \mathrm{mg} / \mathrm{l})$ and wells $(0.91)$ were found to exceed SON permissible limit of $0.2 \mathrm{mg} / \mathrm{l}$ as depicted in Fig. 3(a). Mg is attributed to Mg-rich carbonates in the aquifer of both the boreholes and wells such as basalts, kaolinite, and hematite according to Trostle et al. (2014). Likewise, Nwankwoala et al. (2014) found Mg range of $0.52-1.23 \mathrm{mg} / 1$ with mean values of $0.89 \mathrm{mg} / 1 \mathrm{for}$ boreholes in Yenagoa which was attributed to $\mathrm{Mg}$ dissolution from minerals such as feldspar and mica while a range of 68-173 mg/l was obtained for groundwater in Manali region of India by Antony et al. (2008). Also, Devic et al. (2014) linked Mg in groundwater of Serbia to domestic effluents, minerals, and application of chemical fertilizers. Nonetheless, for adults, hard water rich in magnesium was associated with decrease in cardiovascular diseases as mentioned by Anne (2011).

The mean nitrate $\left(\mathrm{NO}_{3}\right)$ concentration in well (96.25 $\mathrm{mg} / \mathrm{l})$ exceeded the SON permissible limit of $50 \mathrm{mg} / \mathrm{l}$ as depicted in Fig. 3(b) while surprisingly, the mean nitrate concentration of boreholes $(3.77 \mathrm{mg} / \mathrm{l})$ was below the limit. High nitrate range of $0.02-42.45 \mathrm{mg} / \mathrm{l}$ was also reported by Devic et al. (2014) and was linked to anthropogenic sources. High nitrate concentration causes methemoglobinemia in infants (Khan et al., 2013; Saeedi et al., 2012) and some cancers according to Ward et al. (2005). Therefore, it is imperative to 
Table 4 Comparison of well and borehole sample parameters with drinking water guidelines by WHO (2006) and SON (2007)

\begin{tabular}{|c|c|c|c|}
\hline Parameter & WHO & $\mathrm{SON}$ & $\begin{array}{l}\text { Samples which exceed } \\
\text { WHO and SON permissible limits }\end{array}$ \\
\hline Cadmium, $\mathrm{Cd}\left(\mathrm{mgL}^{-1}\right)$ & 0.003 & 0.003 & ND \\
\hline Chloride, $\mathrm{Cl}\left(\mathrm{mgL}^{-1}\right)$ & - & 250 & None \\
\hline Chromium, $\mathrm{Cr}\left(\mathrm{mgL}^{-1}\right)$ & 0.050 & 0.050 & ND \\
\hline Copper, $\mathrm{Cu}\left(\mathrm{mgL}^{-1}\right)$ & 2.000 & 1.000 & - \\
\hline Iron, $\mathrm{Fe}\left(\mathrm{mgL}^{-1}\right)$ & - & 0.300 & None \\
\hline Lead, $\mathrm{Pb}\left(\mathrm{mgL}^{-1}\right)$ & 0.001 & 0.010 & All \\
\hline Zinc, $\mathrm{Zn}\left(\mathrm{mgL}^{-1}\right)$ & - & 3.000 & None \\
\hline Nickel, Ni $\left(\mathrm{mgL}^{-1}\right)$ & 0.020 & 0.020 & None \\
\hline Nitrate, $\mathrm{NO}_{3}^{-}\left(\mathrm{mgL}^{-1}\right)$ & - & 50.000 & Well 1, Well 2, Well 3 \\
\hline $\mathrm{pH}$ & - & $6.5-8.5$ & All (Acidic) \\
\hline Sulfate, $\mathrm{SO}_{4}{ }^{2-}\left(\mathrm{mgL}^{-1}\right)$ & 500 & 100 & None \\
\hline Total coliform $\mathrm{cfu} / \mathrm{mL}$ & $0 \times 10^{2}$ & 10 & All \\
\hline E. coli count $\mathrm{cfu} / \mathrm{mL}$ & $0 \times 10^{2}$ & - & All \\
\hline Electrical conductivity $\left(\mathrm{mScm}^{-1}\right)$ & 1000 & 1000 & None \\
\hline Total suspended solids $\left(\mathrm{mgL}^{-1}\right)$ & - & - & \\
\hline Total solids $\left(\mathrm{mgL}^{-1}\right)$ & - & - & \\
\hline Total dissolved solids $\left(\mathrm{mgL}^{-1}\right)$ & 500 & 500 & None \\
\hline Total hardness (mg/l) & & 150 & BH7,BH8, BH9, Well 1, Well 2, Well 3 \\
\hline Salinity $(\%)$ & - & - & \\
\hline Turbidity (NTU) & 1 & 5 & None \\
\hline Magnesium $(\mathrm{Mg})\left(\mathrm{mgL}^{-1}\right)$ & 200 & 0.2 & All \\
\hline Calcium $(\mathrm{Ca})\left(\mathrm{mgL}^{-1}\right)$ & 200 & & None \\
\hline Sodium $(\mathrm{Na})\left(\mathrm{mgL}^{-1}\right)$ & 200 & 200 & None \\
\hline Dissolved Oxygen $\left(\mathrm{mgL}^{-1}\right)$ & 4 & 7.5 & All \\
\hline $\mathrm{BOD}_{5}\left(\mathrm{mgL}^{-1}\right)$ & & 6 & None \\
\hline
\end{tabular}

WHO World Health Organization, SON Standards Organization of Nigeria

ensure infants are given alternative potable water or ensure that groundwater sourced especially from boreholes only is given to infants and that they are treated before consumption. High nitrate concentration

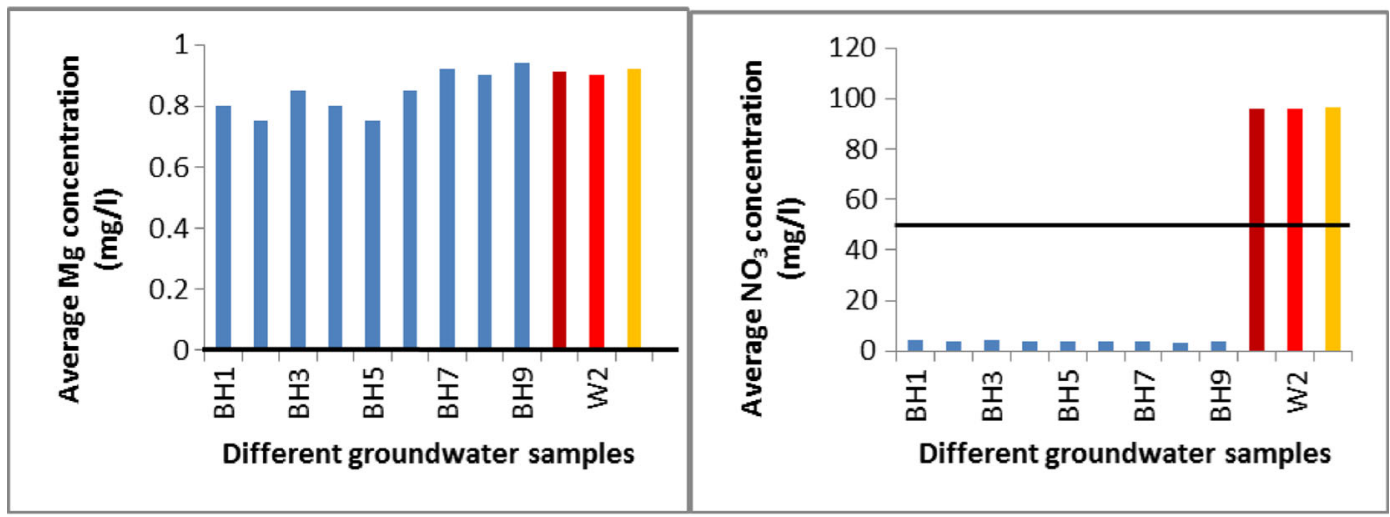

(a)

(b)

Fig. 3 a and $\mathbf{b}$ showing average concentrations of $\mathrm{Mg}$ and $\mathrm{NO}_{3}$ in boreholes and wells 
$>3 \mathrm{mg} / \mathrm{l}$ is usually associated with anthropogenic pollution sources such as poor septic systems and poor disposal of domestic wastewaters as mentioned by Kim et al. (2014) which is prevalent in the study area. Besides, most of the wells are open and poorly maintained which increases their susceptibility to anthropogenic pollutants. Nitrate, which is a key index of anthropogenic pollution according to Han et al. (2014), can be removed from groundwater by Pur Purifier which achieved $92.3 \%$ removal efficiency according to Sojobi et al. (2015), through the use of nano-sized magnetite which achieved nitrate removal efficiency range of 67.3-79.1\% as mentioned by Cho et al. (2015) and combination of nano-filtration and reverse osmosis as described by Epsztein et al. (2015).

The presence of lead $(\mathrm{Pb})$ in both the borehole and well water samples is of health significance. The mean $\mathrm{Pb}$ values of 0.03 and 0.04 exceeded the SON and WHO recommended limits of 0.01 and $0.001 \mathrm{mg} / \mathrm{l}$ as depicted in Fig. 4(a). Pb was also reported by Oni and Hassan (2013) for a site close to a landfill. Hence, the source of $\mathrm{Pb}$ could be attributed to disposal of domestic waste materials containing $\mathrm{Pb}$ close to the wells and boreholes owing to the poor waste disposal practices, absence of centralized disposal system in the study area, and absence of industrial activities in the area. $\mathrm{Pb}$ could cause subencelophalopathic and neurological disorders as reported by WHO (1993). Moderate levels of $\mathrm{Pb}$ could lead to hearing loss, inhibit growth, and learning disabilities while high levels of $\mathrm{Pb}$ could cause convulsion, organ failure, coma, and death (Khan et al., 2013) as well as tiredness, abdominal discomfort, and anemia as reported by Gerlach et al. (2002). Accumulative toxicity of $\mathrm{Pb}$ could lead to $\mathrm{Pb}$ poisoning which harms the stomach (Shu et al., 2011). Exposure to high dose of $\mathrm{Pb}$ could also lead to miscarriage in pregnant women and could damage male organ of reproduction as reported by Sojobi et al. (2014).

The mean phosphate concentration obtained for borehole of $14.27 \mathrm{mg} / \mathrm{l}$ was lower than $15.6 \mathrm{mg} / \mathrm{l}$ obtained for well water although both were less than the phosphate concentration in public tap of $27.5 \pm 0.9 \mathrm{mg} / 1$ reported by Sojobi et al. (2014) but higher than the range of $6.9-19.9 \mathrm{mg} / \mathrm{l}$ reported by Ishaku et al. (2011) for boreholes in Mararaba-mubi, Northeast of Nigeria, who attributed the sources to organic decomposition, domestic effluent, and sewage and fertilizer. The mean sulfate concentrations in both boreholes and wells were 5.6 and $5.5 \mathrm{mg} / 1$, respectively, and were within the SON permissible limits of $100 \mathrm{mg} / \mathrm{l}$. Also, they were found to be lower compared to the range of $12-36.3 \mathrm{mg} / \mathrm{l}$ with mean of 20.4 obtained for groundwater located in Mararaba-mubi, Northeast of Nigeria (Ishaku et al., 2011). Correlation studies revealed a high positive correlation $\left(R^{2}=0.82\right)$ between sulfate and $\mathrm{Pb}$. It could portray that they have similar anthropogenic origin. This suggests that domestic wastewater from the area contains both ions. Therefore, residents should endeavor to dispose wastewaters in the provided drainage and far away from boreholes and wells where there is no provision of drainage.

The mean Ca concentrations of 3.67 and $21 \mathrm{mg} / \mathrm{l}$ of both the boreholes and wells were lower compared to $49.3 \mathrm{mg} / 1$ reported by (Viswanath et al., 2015) but were higher when compared to $2.97 \mathrm{mg} / \mathrm{l}$ for Yenagoa (Nwankwoala et al., 2014) which is a riverine area. This could suggest that $\mathrm{Ca}$ concentration decreases towards the coast. The mean $\mathrm{Ca}$ concentration was within the SON permissible limit of $200 \mathrm{mg} / \mathrm{l}$. Nwankwoala et al. (2014) attributed the Ca concentration to dissolution of feldspars and micas while (Kim et al., 2014) attributed $\mathrm{Ca}$ to precipitation of carbonate minerals during silicate dissolution. Similarly, the mean Potassium (K) concentration in the boreholes and wells were 7.2 and $5 \mathrm{mg} / \mathrm{l}$, respectively, and were higher than the mean of 4.9 and $0.91 \mathrm{mg} / \mathrm{l}$ obtained by Ishaku et al. (2011) and Trostle et al. (2014)], respectively. The high correlation between $\mathrm{Ni}\left(R^{2}=0.92\right)$ and $\mathrm{Zn}\left(R^{2}=0.89\right)$ suggests similar source of origin which could be from the aquifer rocks and minerals.

Trace elements such as $\mathrm{Cr}$ and $\mathrm{Cd}$ were not detected in both the boreholes and wells while $\mathrm{Ni}, \mathrm{Zn}$, and $\mathrm{Fe}$ were of insignificant concentrations in the groundwater of the study area. Though Cd was not detected in all the water samples, exposure to lower $\mathrm{Cd}$ for a long time could cause kidney diseases while exposure at high dosage level could lead to vomiting, albuminuria, and osteomalacia (Sojobi et al., 2014; Skrzypek et al., 2013).

\section{Correlation analyses}

For our study, the following classifications were used: perfectly correlated $\left(R^{2}=1\right)$, very strongly correlated $\left( \pm 0.9 \leq R^{2} \leq 1\right)$, strongly correlated $\left( \pm 0.7 \leq R^{2}< \pm 0.9\right)$, moderately correlated $\left( \pm 0.5 \leq R^{2}< \pm 0.9\right)$, and poorly correlated $\left(R^{2}< \pm 0.5\right)$. Correlation values for all the parameters were shown in Table 4. The correlation studies revealed that the major cations contributing to 
(a)

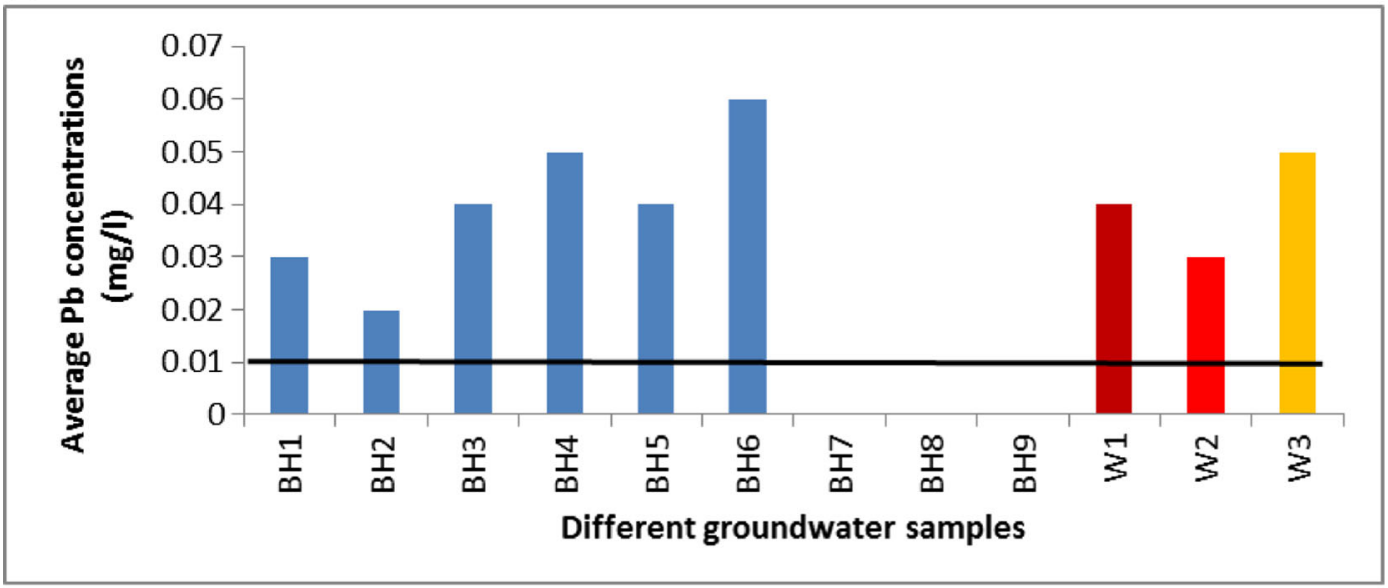

(b)

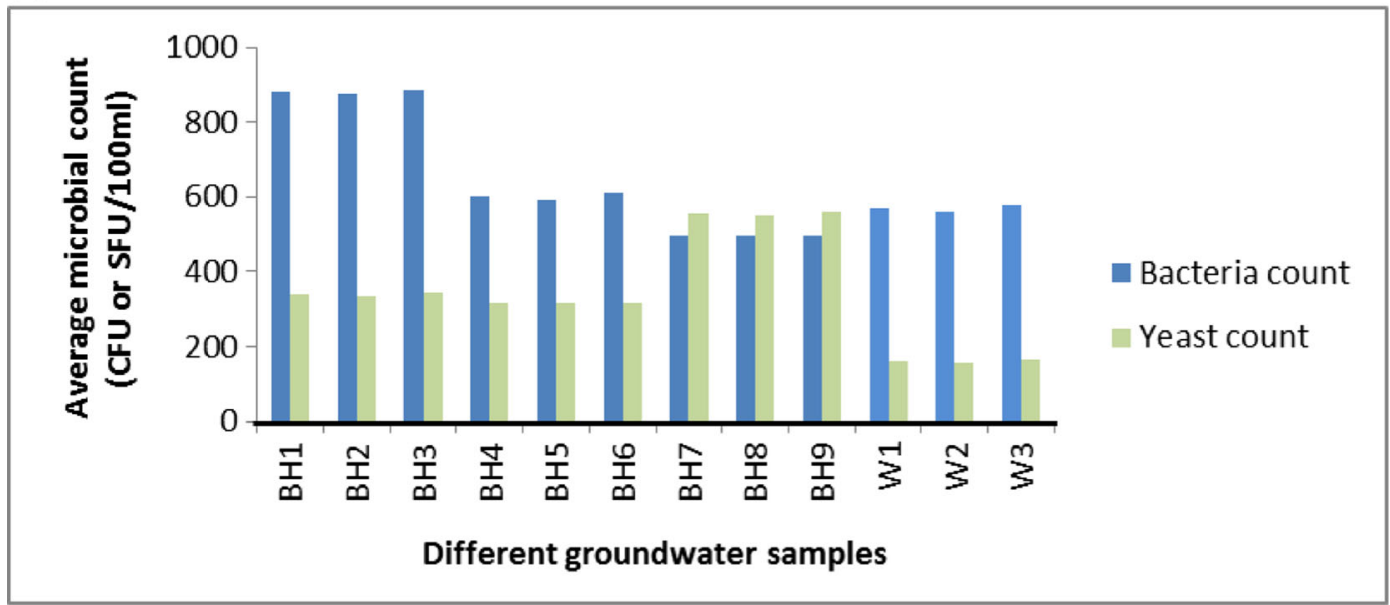

Fig. 4 a Average $\mathrm{Pb}$ concentration in boreholes and wells. b Average microbial count in boreholes and wells

TS which are very strongly and strongly correlated to TS are $\mathrm{Na}(0.91), \mathrm{K}(0.86)$, and $\mathrm{Mg}(-0.84)$ while in terms of TDS, the major contributing cations which have strong and very strong correlations with TDS are $\mathrm{Ca}(0.92), \mathrm{Na}(0.90), \mathrm{Mg}(0.87)$, and $\mathrm{Fe}(0.80)$, as well as the anions $\mathrm{NO}_{3}(0.80)$ and $\mathrm{DO}(0.84)$. This finding corroborates the results obtained by Viswanath et al. (2015) that $\mathrm{Ca}$ is the most significant parameter for predicting TDS. Our results also showed that the second and third most important parameter for predicting TDS were $\mathrm{Na}$ and $(0.90)$ and $\mathrm{Mg}(0.87)$ for our study area. Of all the cations, $\mathrm{Na}$ with correlation value of 0.89 is the major contributor to total hardness alongside $\mathrm{Ni}, \mathrm{K}$, and $\mathrm{Mg}$ with correlation values of $0.89,0.88$, and 0.81 , respectively, and the anion, $\mathrm{PO}_{4}$ with negative correlation value of -0.82 . The correlation results revealed that the three major mineral groups responsible for TH, TS, and TDS in the groundwater are Ca-Fe group (0.96), $\mathrm{Na}-\mathrm{Mg}$ group (0.89), and $\mathrm{Zn}-\mathrm{K}$ group (0.89), which seem to control the chemical composition of the groundwater. The fourth mineral group is the $\mathrm{Pb}$ group.

While chloride ion $\left(\mathrm{Cl}^{-}\right)$is associated with the $\mathrm{Zn}-\mathrm{K}$ group with strong/very strong correlations (0.97/0.84), $\mathrm{NO}_{3}$ is linked with Ca-Fe group with perfect/very strong correlations (1.00/0.96). $\mathrm{Mg}$ and $\mathrm{Ca}$ did not show any correlation with any of the anions studied. It is likely the $\mathrm{Mg}^{2+}$ and $\mathrm{Ca}^{2+}$ are associated with bicarbonate minerals $\left(\mathrm{HCO}_{3}{ }^{-}\right)$as mentioned by Skrzypek et al. (2013). The major anions associated with $\mathrm{Pb}$ are $\mathrm{SO}_{4}^{2-}$ and $\mathrm{PO}_{4}^{2-} . \mathrm{Pb}$ and $\mathrm{Ni}$ had strong negative correlation value of -0.87 which suggests a high dependency on each other and possible similar anthropogenic source (Devic et al., 
2014), and they both have low concentration level in the groundwater. In like manner, $\mathrm{Pb}$ and $\mathrm{SO}_{4}^{2-}$ are strongly correlated (0.82) and suggest originating from similar anthropogenic sources such as domestic wastewaters and effluents. $\mathrm{PO}_{4}^{2-}$ is very strongly correlated with $\mathrm{Ni}$ and $\mathrm{Zn}$ with the same correlation value of -0.98 and strongly correlated with $\mathrm{Pb}(0.82)$ which seems to portray similar anthropogenic origin considering similar low concentration levels of the trace metals.

Likewise, the correlation results revealed the prevalent ionic exchange and affinity occurring in the groundwater aquifer system (Kim et al., 2014; Skrzypek et al., 2013). It was observed that $\mathrm{Cl}$ has strong preferential affinity for $\mathrm{Zn}>\mathrm{Ni}>\mathrm{K}$ in and while $\mathrm{NO}_{3}$ has perfect affinity for $\mathrm{Fe}(1)$ and very strong affinity for $\mathrm{Ca}(0.96)$ while $\mathrm{SO}_{4}^{2-}$ and $\mathrm{PO}_{4}^{2-}$ prefer $\mathrm{Pb}$. In addition, the $\mathrm{Mg}$ rich aquifer encourages the dissolution of $\mathrm{Mg}$ into the aquifer. Even though it is dissolved, it is not a preferred cation by the major anions in the aquifer minerals. This scenario is responsible for the high level of $\mathrm{Mg}$ in both the groundwater and well. This finding corroborated results obtained by Akri (2015) that groundwater chemistry is mainly influenced by dissolution of halite, reverse ion exchange, and anthropogenic sources. The low ionic $\mathrm{Na} / \mathrm{Cl}$ ratio of 0.12 suggests prevalence of halite sources in the boreholes while the high $\mathrm{Na} / \mathrm{Cl}$ ratio of 2.84 for wells suggests Na-rich carbonate sources according to Hillel et al. (2015). Furthermore, low ionic ratio of $\mathrm{Mg} / \mathrm{Ca}$ of 0.2 and 0.04 for the boreholes and wells which is $<0.5$ indicated dissolution of limestone or gypsum in the aquifer as mentioned by Vengosh and Rosenthal (1994).

The turbidity of the groundwater was found to be strongly dependent on the $\mathrm{Cl}, \mathrm{NO}_{3}^{-}$, and Fe concentrations as well as the $\mathrm{pH}$ and electrical conductivity (EC) of the groundwater. The EC was found to be very strongly correlated with $\mathrm{DO}(0.99), \mathrm{NO}_{3}^{-}(-0.99), \mathrm{Fe}$ (-0.99), $\mathrm{Ca}(-0.96), \mathrm{pH}(0.97)$, and $\mathrm{BOD}_{5}(0.94)$. This shows that $\mathrm{DO}, \mathrm{NO}_{3}^{-}, \mathrm{Fe}, \mathrm{Ca}, \mathrm{pH}$, and BOD5 can be used as a predictor for $\mathrm{EC}$ while $\mathrm{NO}_{3}^{-}, \mathrm{Fe}, \mathrm{DO}, \mathrm{Ca}$, and $\mathrm{BOD}_{5}$ can be used to predict $\mathrm{pH}$.

\section{Microbiological parameters}

Statistics of microbiological analyses of the groundwater samples of the study area is shown in Table 4 . Isolated microorganisms from the borehole and well water samples were Enterobacter aerogenes and E. coli. E. coli and E. aerogenes are characteristics of the intestinal tract of man and animals (Thakur et al., 2012). E. aerogenes occurs mostly on grains and plant surfaces but may also inhabit the feces of man and animals. Their presence in borehole water is an indicator that the borehole water was contaminated with feces of man or animals or both as mentioned by Mackie, et al. (Mackie et al., 2006). E. aerogenes was also found in borehole water samples in Ilorin metropolis especially in surroundings that were littered with animal and fowl droppings as observed by Agbabiaka and Sule (2010). This situation is also typical of the borehole and well surroundings in Omu Aran where droppings from domesticated goats and sheep litter the surroundings of domestic homes, close proximity of poorly designed septic tanks coupled with widespread practice of open defecation owing to absence of good latrines in most homes.

E. aerogenes was also reported by Okiki and Ivbijaro (2013) and Thakur et al. (2012) in boreholes and wells in Imota, Lagos State, and water sources in Sloan City, Pradesh, respectively, while E. coli and E. aerogenes were reported by Jacinta and Adebayo (2015) in well and borehole water in Gwagwalada in Abuja, Nigeria. E. aerogenes alongside other microbes could cause illnesses such as fever, chills, headache, weakness, skin rash, sneezing and coughing, diarrhea, and abdominal pain (Okiki and Ivbijaro, 2013).

Contrary to the view of Mackie et al. (2006) that E. aerogenes is non-pathogenic in healthy individuals, Adejuwon et al. (2011) and Dauda (2010) found that they pose health risks to humans since they were found resistant to common antibiotics such as streptomycin, tetracycline, and ampicillin alongside $E$. coli. In addition, Olufemi and Oluwole (2012) alleged that E. coli and E. aerogenes were part of the leading fecal coliforms responsible for cholera outbreak in Ibadan.

For all the wells and most of the boreholes, the E. coli (bacteria) counts were greater than the yeast counts as depicted in Fig. 4(b). The average total coliform (TC) count in well water of $1100 \mathrm{MPN} / 100 \mathrm{ml}$ was higher than that of borehole with $803.33 \mathrm{MPN} / 100 \mathrm{ml}$. This revealed that TC was highly attenuated in the boreholes more than the wells according to Donohue et al. (2015). The mean E. coli count in borehole of $658.33 \mathrm{CFU} /$ $100 \mathrm{ml}$ was greater than that of well of $570 \mathrm{CFU} / 100 \mathrm{ml}$. Also, the yeast count of $403.67 \mathrm{CFU} / 100 \mathrm{ml}$ in borehole was greater than $160 \mathrm{CFU} / 100 \mathrm{ml}$ obtained in well water samples. Furthermore, fungi was not detected in both well and borehole water samples. In addition, spore- 


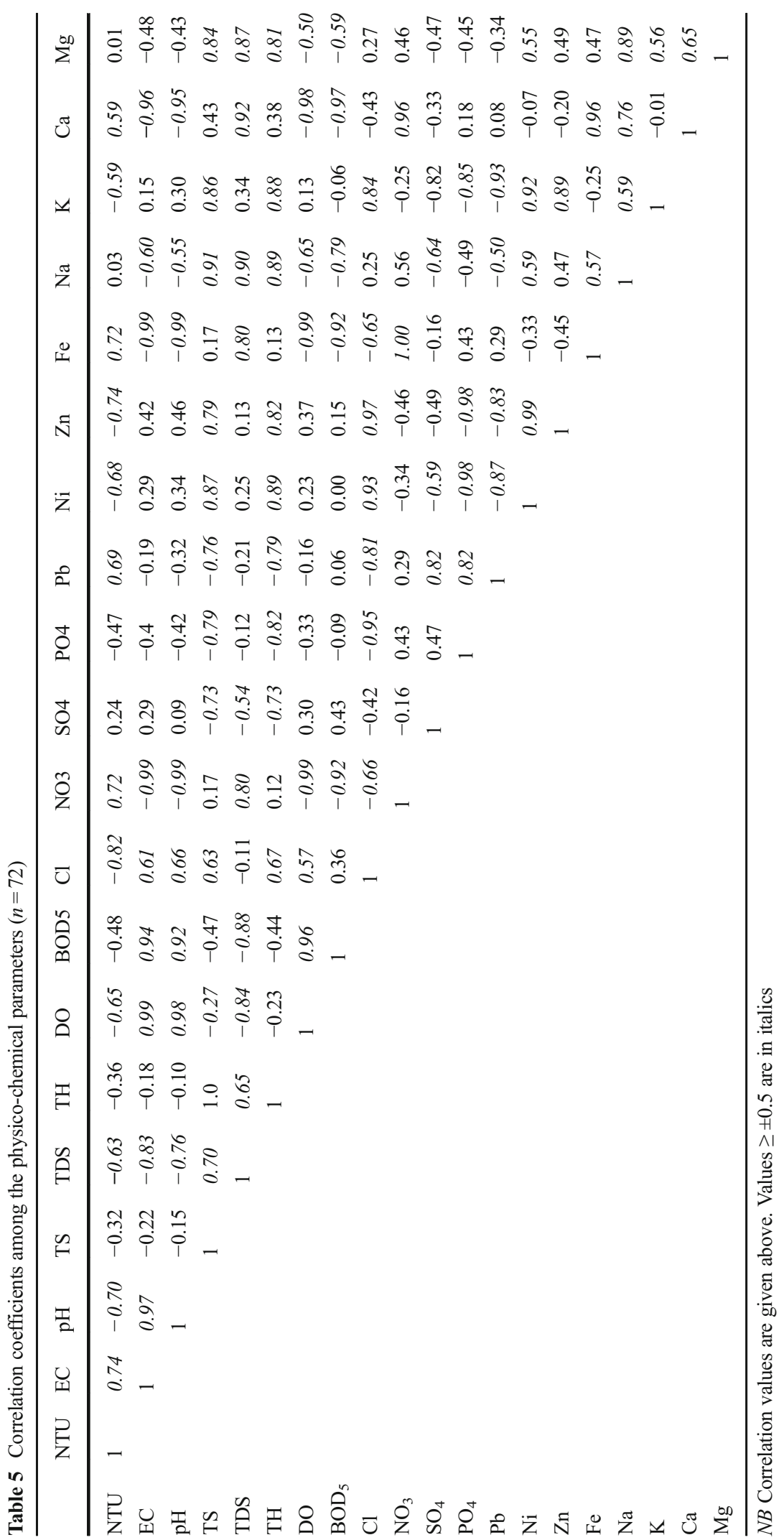


Table 6 Statistics of microbiological analyses of the groundwater resources of the study area

\begin{tabular}{|c|c|c|c|c|c|c|c|c|c|c|}
\hline \multirow[t]{2}{*}{ Parameters } & \multicolumn{5}{|l|}{ Borehole } & \multicolumn{5}{|l|}{ Wells } \\
\hline & No. of Data & Max & Min & Avg & $\mathrm{SD}$ & No. of Data & Max & Min & Avg & $\mathrm{SD}$ \\
\hline TC (MPM/100 ml) & 54 & 1110 & 1090 & 803.33 & 778.65 & 18 & 1105 & 1095 & 1100 & 4.08 \\
\hline E-Coli (CFU/100 ml) & 54 & 885 & 494 & 658.33 & 561.58 & 18 & 580 & 560 & 570 & 8.16 \\
\hline Yeast (SFU/100 ml) & 54 & 560 & 315 & 403.67 & 346.68 & 18 & 165 & 155 & 160 & 4.08 \\
\hline Fungi (SFU/100 ml) & 54 & ND & ND & ND & ND & 18 & ND & ND & ND & ND \\
\hline
\end{tabular}

$T C$ total coliform, Max maximum, Min minimum, Avg average, $S D$ standard deviation

forming yeasts were found in all the borehole and well water samples. Yeast contamination was also found in groundwater resources in Umudike in Abia State, Benin City, Calabar, and Jos (Ayanbimpe et al., 2012; Erah ]et al., 2002; Obi and George, 2011; Okpako et al., 2009). The isolated species were Mucor racemosus, Aspergillus niger, Rhizopus, Fusarium, Penicillium, Candida tropicalis, Candida lipolytica, and Rhodotorula sp. (Ayanbimpe et al., 2012; Obi and George, 2011; Okpako et al., 2009).

Therefore, in order to avert outbreak of water-borne diseases in the study area, it is imperative that the community dwellers always treat their drinking water by use of water guard which was found effective in removing bacterial contamination in the various water sources in the study area as recommended by Sojobi et al. (2014).

For the physico-chemical parameters of well water samples, ANOVA test indicated that there was no significant difference since the F-statistic value of 0.00089 obtained was $<$ the critical value of 3.52. Likewise, the ANOVA test also showed that there was no significant difference in the physico-chemical parameters of the borehole samples since the F-test statistic of 0.358 obtained was $<2.64$ critical value. Comparison of the mean values of the well and borehole samples using the $t$ test indicated that there was no sufficient evidence to show significant difference in their physico-chemical parameters since the $t$ test value of 0.05693 obtained lies within the critical values of +2.080 and -2.080 for a two-tailed test at 0.05 significance level (Table 5).

Furthermore, ANOVA test for the microbiological parameters of the well samples indicated that there was no significant difference since the F-statistic value of 5.03 was $<5.14$ critical value. The $p$ value obtained for the Fstatistic value was 0.053 and was $>0.053$. The ANOVA test carried out for the microbiological parameters of borehole samples showed that there was significant difference since the F-statistic value of 8.55 was $>2.51$ critical value obtained at 0.05 significance level. Therefore, we reject the null hypotheses and accept the alternative hypothesis that there was significant difference in the microbiological parameters of the borehole samples as recommended by Bluman (2013). Comparison of the mean values of the well and borehole samples using the $t$ test showed that there was no significant difference in their microbiological parameters since the $t$ test value of -0.07 lies within the critical values of +4.303 and -4.303 obtained at 0.05 significance level (Table 6).

Therefore, it can be deduced that the geological formation in the study area seems to be similar but the microbiological characteristics of the aquifer where each borehole and well were located tend to be different subject to ease of contamination. This implies that owners of wells and boreholes should ensure they are located professionally constructed and located in an environment that offers maximum protection form exogenous, anthropogenic potential sources of contamination.

\section{Conclusion}

The need for regular monitoring and protection of groundwater sources has been pointed out by several studies (Bacquart et al., 2015; Oyelami et al., 2013; Porowska, 2014; Rao, 2014; Vasanthaviger et al., 2013; Wanke et al., 2015), and it is re-emphasized in this study. Oftentimes, the necessity for treatment and the type of treatment required is only brought to the fore through such regular exercise which is often oblivious to the consumers and industrial users. Awareness of the type and potential sources of contaminants guides selection of appropriate and cost-effective treatment methods and safeguards consumers from potential health risks associated with contaminants from untreated 
groundwater sources and likewise guide the location and construction of boreholes and wells for domestic and industrial uses.

In developing countries where regular monitoring of groundwater resources is grossly lacking or inadequate, consumers, homeowners, and industrial users of groundwater should take it in their strides to carry out such exercise periodically. Also, domestic wastewaters and effluents should be appropriately disposed away from boreholes and wells to guard against leaching of heavy metals and other potential contaminants into the aquifer. Such boreholes and wells should be covered always while periodic maintenance and treatment should be carried out to keep them in good potable condition. Movements of domesticated animals such as goats and sheep should be restrained from locations of boreholes and wells to eliminate or reduce the risk of microbiological contamination.

Government should also endeavor to provide effective drainage system and appropriate solid waste disposal systems in rural areas. Such investment will go a long way to preserve the integrity and potability of the groundwater resources in such communities. In addition, government should set up monitoring network to periodically assess the groundwater in the state so as to identify potential sources of pollution before it reaches alarming levels. Local governments should also set up task force to ensure every residential house in the rural and peri-urban areas has appropriate sewage disposal systems and septic tanks to reduce microbial contamination of the groundwater resources in such areas.

\section{References}

Abatneh, Y., Sahu, O., \& Yimer, S. (2014). Purification of drinking water by low cost method in Ethiopia. Applied Water Science, 4, 357-362.

Abd El-Salam, M. M. A., \& Abu-Zuid, G. I. (2015). Impact of landfill leachate on the groundwater quality: a case study in Egypt. Journal of Advanced Research, 6, 579-586.

Adejuwon, A. O., Bisi-John, M. A., Agboola, O. A., Fadeyi, B. O., \& Adejuwon, A. O. (2011). Antibiotics sensitivity patterns of Escherichia coli and Aerobacter aerogenes isolated from well water in Ile-Ife, Nigeria. International Journal of Medicine and Medical Sciences, 3(5), 155-160.

Agbabiaka, T. O., \& Sule, I. O. (2010). Bacteriological assessment of selected borehole water samples in Ilorin Metropolis. IJABR, 2(2), 31-37.

Akhtar, M. M., Tang, Z., \& Mohamadi, B. (2014). Contamination potential assessment of potable groundwater in Lahore. Polish Journal of Environmental Studies, 23(6), 1095-1916.
Akinyemi, J. O., \& Souley, S. O. (2014). Monitoring the quality of some sources of irrigation water in different parts of Ogun State, Nigeria. IERI Proceedings, 9, 123-128.

Akri, B. (2015). Hydrochemical processes regulating groundwater quality in the coastal plain of Al Musanaah, Sultanate of Oman. Journal of African Earth Sciences, 106, 87-98.

Al-ahmadi, M. E., \& El-Fiky, A. A. (2009). Hydrogeochemical evaluation of shallow alluvial aquifer of Wadi Marwani, western Saudi Arabia. Journal of King Saudi University, 21, 179-190.

American Public Health Association Standard methods for the examination of water and wastewater, $18^{\text {th }} \mathrm{ed}$., Washington DC, 1992

American Public Health Association Standard methods for the examination of water and wastewater, $22^{\text {nd }}$ ed., Washington DC, 2012

Anne, A. (2011). Magnesium and Calcium in drinking water and heart diseases. Encyclopedia of Environmental Health 535544

Antony, S. A., Balakrishnan, M., Gunasekaran, S., \& Natarayan, R. K. (2008). A correlation study of the ground water quality in the Manali Petroleum Industrial Region in Tamil Nadu, India. Indian Journal of Science and Technology, 1(6), 1-11.

Ayanbimpe, G. M., Abbah, V. E., \& Ior, C. A. (2012). Yeasts and yeast-like fungal contaminants of water used for domestic purposes in Jos, Nigeria. Microbiology Research, 3(e24), 99102.

Ayandiran, T. A., Ayandele, A. A., Dahunsi, S. O., \& Ajala, O. O. (2014). Microbial assessment and prevalence of antibiotic resistance in polluted Oluwa River, Nigeria. Egyptian Journal of Aquatic Research, 40(291), 299.

Bacquart, T., Frisbie, S., Mitchell, E., Grigg, L., Cole, C., Small, C., \& Sakar, B. (2015). Multiple inorganic toxic substances contaminating the groundwater of Myingyan Township, Myanmar: Arsenic, manganese, fluoride, iron, and uranium. Science of the Total Environment, 517, 232-245.

Baguma, D., Hashim, J. H., Aljunid, S. M., Hauser, M., Jung, H., \& Loiskandl, W. (2012). Safe water, household income and health challenges in Ugandan homes that harvest rainwater. Water Policy, 14, 977-990.

Biswas, A. K. (2008). Integrated water resources development: Is it working?'. Water Resources Development, 24(1), 5-22.

Biswas, A. K., \& Tortajada, C. (2010). Future water governance: problems and perspectives. International Journal of Water Resources, 26(2), 129-139.

Bluman, A. G. (2013). Elementary Statistics. A step by step by step approach (6th ed.). New York: McGraw Hill.

Cho, D.-W., Song, H., Schwartz, F. W., Kim, B., \& Jeon, B. H. (2015). The role of magnetite nanoparticles in the reduction of nitrate in groundwater by zero-valent iron. Chemosphere, $125,41-49$.

Dahunsi, S. O., Ayandiran, T. A., Oranusi, U. S., \& Owamah, H. I. (2014). Drinking water quality and public health of selected communities in South Western Nigeria. Water Quality, Exposure and Health, 6, 143-153.

Dauda, M. M. (2010). Enterobacteria in drinking water: a public health hazard. RIF, 1(5), 224-230.

Devic, G., Djordjevic, D., \& Sakan, S. (2014). Natural and anthropogenic factors affecting the groundwater in Serbia. Science of the Total Environment, 468-46, 933-942. 
Dinka, M. O., Loiskandl, W., \& Ndambuki, J. M. (2015). Hydrochemical characterization of various surface water and groundwater resources available in Matahara areas, Fantella region of Oromiya region. Journal of Hydrology: Regional Studies, 3, 444-456.

Donohue, S., McCarthy, V., Rafferty, P., Orr, A., \& Flynn, R. (2015). Geophysical and hydrogeological characterisation of the impacts of on-site wastewater treatment discharge to groundwater in a poorly productive bedrock aquifer. Science of the Total Environment, 523, 109-119.

Dwairo, B., Hoko, Z., Love, D., \& Guzha, E. (2006). Assessment of the impacts of pit latrines on groundwater quality in rural areas: a case study from Marondera district of Zimbabwe. Physics and Chemistry of the Earth, 31, 779-788.

Epsztein, R., Nir, O., Lahav, O., \& Green, M. (2015). Selective nitrate removal from groundwater using a hybrid nanofiltration-reverse osmosis filtration scheme. Chemical Engineering Journal, 279, 372-378.

Erah, P. O., Akujieze, C. N., \& Oteze, G. E. (2002). The quality of groundwater in Benin City: a baseline study on inorganic chemicals and microbial contaminants of health importance in boreholes and open wells. Tropical Journal of Pharmaceutical Research, 1(2), 75-82.

Estache, A. (2008). Infrastructure and development: a survey of recent and upcoming issues. In F. F. Bourguigon \& B. Pleskovic (Eds.), Rethinking infrastructure for development (pp. 47-82). World Bank: Washington DC.

Falkenmark, M. (2015). Adapting to climate change: towards societal water insecurity in dry-climate countries'. International Journal of Water Resources Development, 25(2), 123-136.

Fay, M., Limi, A., \& Perrissin-Fabert, B. (2010). Financing greener and climate-resilient infrastructure in developing countries: challenges and opportunities. EIB, 15, 34-58.

Freeze R. A., \& Cherry J. A. (1979). Groundwater. Prentice-Hall, Englewood. Cliffs, NJ, USA.

Gerlach, R. F., Cury, J. A., Krug, F. J., \& Kine, S. R. (2002). Effect of lead on dental enamel formation. Toxicology, 175, 27-34.

Gutierrez, E. G., Gomez, F. G., \& Guardiola, J. (2013). Water access in Sucre, Bolivia; a case of governance deficit. International Journal of Water Resources Development, 29(4), 636-649.

Gwenzi, W., Dunjana, N., Pisa, C., Tauro, T., \& Nyamadzawo, G. (2015). Water quality and public health risks associated with roof rainwater harvesting systems for potable supply: review and perspectives. Water Quality Ecology. doi:10.1016/j. swaqe2015.01.006.

Han, S., Wu J., Zhang, Y., Cai, Z., Feng, Y., Yao, Q., Li, X., Liu, Y., \& Zhang, M. (2014). Characteristics and formation mechanism of a winter hazeefog episode in Tianjin, China. Atmospheric Environment 98, 323-330.

Hillel, N., Geyer, S., Licha, T., Khayat, S., Laronne, J. B., \& Siebert, C. (2015). Water quality and discharge of the Lower Jordan River. Journal of Hydrology, 527, 1096-1105.

Huang, W. J., Chen, W.-Y., Chuang, Y.-H., Lin, Y.-H., \& Chen, H.W. (2014). Biological toxicity of groundwater in a seashore area: causal analysis and its spatial pollutant pattern. Chemosphere, 100, 8-15.

Ishaku, J. M., Kaigama, U., \& Onyeka, N. R. (2011). Assessment of groundwater quality using factor analysis in Mararaba-mubi area, Northeastern Nigeria.
Journal of Earth Sciences and Geotechnical Engineering, 1(1), 9-33.

Jacinta, A. N., \& Adebayo, I. A. (2015). Determination of coliforms in different sources of drinking water in Gwagwalada Abuja. Report and Opinion, 7(1), 1-6.

Jackson, R. B., Carpenter, S. R., Dahm, C. N., McKinght, D. M., Postel, S. L., \& Running, S. W. (2001). Ecological Applications, 11(4), 1027-1045.

Khan, S., Shahnaz, M., Jehai, N., Rehman, S., Shah, M. T., \& Din, S. (2013). Drinking water quality and human health risk in Charsadda district, Pakistan. Journal of Cleaner Production, 60, 93-101.

Kim, K.-H., Yun, S.-T., Park, S.-S., Joo, Y., \& Kim, T.-S. (2014). Model-based clustering of hydrochemical data to demarcate natural versus human impacts on bedrock groundwater quality in rural areas, South Korea. Journal of Hydrology, 519, 625-636.

Kumar, P., Bansod, B. K. S., Debnath, S. K., Thakur, P. K., \& Ghashyam, C. (2015). Index-based groundwater vulnerability mapping models using hydrogeological settings: a critical evaluation. Environmental Impact Assessment Review, 51, 38-49.

KWADP weather record from 2002-2011. [internet]. http://www. kwadp.org/site/index.php?option=com_content\&view $=$ article $\&$ id $=24 \&$ Itemid $=8$

Mackie, R. I., Koike, S., Krapac, I., Chee-Sanford, J., Maxwell, S., \& Aminov, R. I. (2006). Tetracycline residues and tetracycline resistance genes in groundwater impacted by swine production facilities. Animal Biotechnology, 17, 157-176.

Mayzelle, M. M., Viers, J. H., Medellin-Azuara, J., \& Harter, T. (2015). Economic feasibility of irrigated agricultural land use buffers to reduce groundwater nitrate in rural drinking water sources. Water, 17, 12-37.

Melles, Z. M., \& Kiss, S. A. (1992). Influence of the magnesium content of drinking water and of magnesium therapy on the occurrence of preeclampsia. Magnesium Research, 5, 277279.

Mondal, N. C., Singh, V. S., Saxena, V. K., \& Prasad, R. K. (2008). Improvement of groundwater quality due to fresh water ingress in Potharlanka Island, Krishna delta, India. Environmental Geology, 55(3), 595-603.

National Bureau of Statistics (2010). Annual abstract of statistics [internet]., Federal Republic of Nigeria; c2010 [cited 2015 April 20]. Available from www.nigerianstat.gov.ng

NBS/UNICEF/UNFPA Joint Report (2011). Nigeria multiple indicator cluster survey [internet]. c2011 [cited 2015 April 20]. Available from www.nigerianstat.gov.ng/pages/download/ 145

Nwankwoala, H. O., Amadi, A. N., Oborie, E., \& Ushie, F. A. (2014). Hydrochemical factors and correlation analysis in groundwater quality in Yenagoa, Bayelsa State, Nigeria. Applied Ecology and Environmental Sciences, 2(4), 100 105.

Obi, C. N., \& George, P. (2011). The microbiological and physicochemical analysis of borehole waters used by off-campus students of Michael Okpara University of Agriculture, Umudike, Abia State, Nigeria. Research Journal of Biological Sciences, 6(11), 602-607.

Oki, T., Kanae, S. (2006). Global hydrological cycles and world water resources 213 (5790): 1068-1072 
Okiki, P., \& Ivbijaro, J. O. (2013). Bacteriological and physicochemical qualities of well water in Imota-Lagos, Nigeria and health effects associated with its usage. Advances in Life Science and Technology, 13, 18-25.

Okpako, E. C., Osuagwu, A. N., Duke, A. E., \& Ntui, V. O. (2009). Prevalence and significance of fungi in sachet and borehole drinking water in Calabar, Nigeria. African Journal of Microbiology Research, 3(2), 56-61.

Olufemi, F., \& Oluwole, M. F. (2012). Microbiological examination of sachet water due to a cholera outbreak in Ibadan, Nigeria. Open Journal of Medical Microbiology, 2, 115-120.

Oni, A. A., \& Hassan, A. T. (2013). Groundwater quality in the vicinity of Aba-Eku dumpsite, Ibadan, Southwest, Nigeria. A detailed report. Ethiopian Journal of Environmental Studies and Management, 6(6), 589-600.

Oyegoke, S. O., Adeyemi, A. O., \& Sojobi, A. O. (2012). The challenges of water supply for a megacity: a case study of Lagos Metropolis. International Journal of Scientific and Engineering Research, 3(2), 1-10.

Oyelami, A. C., Aladejana, J. A., \& Agbede, O. O. (2013). Assessment of the impact of open waste dumpsites on groundwater quality: a case study of the Onibu-Eja dumpsite, Southwestern Nigeria. Procedia Earth and Planetary Science, 7, 648-651.

Porowska, D. (2014). Assessment of groundwater contamination around reclaimed municipal landfill-Otwock area, Poland. Journal of Ecological Engineering, 15(4), 69-81.

Rao, N. S. (2014). Spatial control of groundwater contamination using principal component analysis. Journal of Earth System Science, 123(4), 715-728.

Saeedi, R., Naddafi, K., Alimohammadi, M., \& Nazmara, S. (2012). Denitrification of drinking water using a hybrid heterophic/autotrophic/BAC bioreactor. Desalination Water Treatment, 45, 1-10.

Sato, M. (2014). Empowering women at home and beyond: applying Japanese experience for poverty alleviation. Development in Practice, 24(7), 840-853.

Shu, W. U., Yue-heng, H. U., \& Dan, Z. U. O. (2011). Discussion on parameter choice for managing water quality of the drinking water source. Procedia Environmental Sciences, 11, $1465-1468$.

Skrzypek, G., Dogramaci, S., \& Grierson, P. F. (2013). Geochemical and hydrological processes controlling groundwater salinity of a large inland wetland of northwest Australia. Chemical Geology, 357, 164-177.

Sobowale, A., Ramalan, A. A., Mudiare, O. J., \& Oyebode, M. A. (2015). Groundwater recharge studies in irrigated lands in Nigeria: implications for basin sustainability. Sustainability Water Quality Ecology. doi:10.1016/j.swaqe.2014.12.004.

Sojobi, A. O., Owamah, H. I., \& Dahunsi, S. O. (2014). Comparative study of household water treatment in a rural community in Kwara State Nigeria. Nigerian Journal of Technology, 33(1), 134-140.

Sojobi, A. O., Dahunsi, S. I., Afolayan, A. O. (2015). Assessment of the efficiency of disinfection methods for improving water quality. Nigerian Journal of Technology 4 (34) in press.

Srinivas, Y., Muthuraj, D., Oliver, D. H., Raj, A. S., \& Chandrasekar, N. (2013). Environmental applications of geophysical methods to map groundwater quality at Tuticorin, Tamilnadu, India. Environmental Earth Science, 70, 21432152.
Standards Organisation of Nigeria (2007). Nigerian standard for drinking water quality [internet] Nigeria; c2007 [cited 2015 April 20] http://www.unicef.org/nigeria/NG_resources_ nigerianstandard4drinkingwater.pdf

Taher, T., Bruns, B., Bamaga, O., Al-Weshali, A., \& Steenbergen, F. V. (2012). Local groundwater governance in Yemen: building on traditions and enabling communities to craft new rules. Hydrogeology, 20, 1177-1188.

Thakur, M., Negi, S., Kumar, A., Patil, S., Kumar, A., \& Sharma, N. (2012). Prevalence and characterization of water contamination indicator bacteria with special reference to coliforms from drinking water supply in Sloan City of Himachal Pradesh. Biological Forum-An International Journal, 4(1), $85-89$.

Todd, D. L. (1980). Groundwater hydrology (pp. 267-315). New York: John Wiley and Sons.

Tortajada, C. (2002). Water infrastructure as an essential element for human development. International Journal of Water Resources Development, 30(1), 8-19.

Tortajada, C. (2010). Water governance: some critical issues'. International Journal of Water Resources Development, 26(2), 297-307.

Trostle, K., Derry, L., Vigier, N., \& Chadwick, O. (2014). Magnesium isotope fractionation during arid pedogenesis on the Island of Hawaii (USA). Procedia Earth and Planetary Science, 10, 243-248.

UNESCO (2009). Water in a changing world. The United Nations World Water Development Report 3, World Water Assessment Programme [internet]. Paris; c2009 [cited 2015 April 15]. http://www.unesco.org/new/en/natural-sciences/ environment/water/wwap/wwdr/wwdr3-2009/

Vasanthaviger, M., Srinivasamoorthy, K., \& Prasanna, M. V. (2013). Identification of groundwater contamination zones and its sources by using multivariate statistical approach in Thirumanimuthar sub-basin, Tamil Nadu, India. Environmental Earth Science, 68, 1783-1795.

Vengosh, A., \& Rosenthal, E. (1994). Saline groundwater in Israel: its bearing on the water crisis in the country. Journal of Hydrology, 156, 389-430.

Verd, V. S., Domingues S. J., Gonzales, Q. M., Vidal, M. M., Mariano, S. A. C., de Roque, C. C., \& Sevilla, M. J. M. (1992). Association between calcium content of drinking water and fractures in children (in Spanish). Anales Españoles de Pediatría, 37, 461-465.

Viswanath, N. C., Kumar, P. G. D., \& Ammad, K. K. (2015). Statistical analysis of quality of water in various water shed for Kozhikode City, Kerala, India. Aquatic Procedia, 4, 1078-1085.

Vorosmarty, C. J., McIntyre, P. B., Gessner, M. O., et al. (2010). Rivers in global crisis: water insecurity for humans and biodiversity. Nature, 467, 555-561.

Wanke, H., Nwakfila, A., Hamutoko, J. T., Lohe, C., Nembo, F., Petrus, I., David, A., Beukes, H., Masule, N., \& Quinger, M. (2015). Hand dug wells in Namibia: an underestimated water source or a threat to human health? Journal of Physical Chemistry. doi:10.1016/j.pce.2015.01.004.

Ward, M. H., Dekok, T. M., Levalliois, P., Brender, J., Gulis, G., Nolan, B. T., \& Van Derslice, J. (2005). Workgroup report: drinking-water nitrate and health recent findings and research needs. Environmental Health Perspectives, 113, 1607-1614. 
Wayland, K., Long, D., Hyndmann, D., Pijanowski, B., Woodhams, S., \& Haack, K. (2003). Identifying relationships between baseflow geochemistry and land use with synoptic, sampling and R-Mode factor analysis. Journal of Environmental Quality, 32, 180-90.

Wiek, A., \& Larson, K. L. (2012). Water, people, and sustainability - a systems framework for analysing and assessing water governance regimes. Water Resources Management, 26, 3153-3171.

World Bank (2011). Framework for strong, sustainable and balanced growth. Rebalancing growth, and development. An interconnected agenda [internet]. Washington DC, World Bank, c2011 [cited 2015 April 15]. Available from www. 10.iadb.org/intalcdi/PE/2011/09183.pdf

World Health Organization (1993). Guidelines for Drinking Water Quality, Vol. 1 - Recommendations (2nd edn.). Geneva, Switzerland.
World Health Organization (1996). The world health report 1996: fighting disease, fostering development [internet]. Geneva; c1996 [cited 2015 April 20]. www.who.int/whr/1996/en/

World Health Organization (2006). Guidelines for Drinking water quality: First Addendum to $3^{\text {rd }}$ Edition [internet]. Geneva; c2006 [cited 2015 April 20] www.who.int/water_sanitation health/dwq/gdwq0506.pdf

Yang, C. Y., \& Chiu, H. F. (1999). Calcium and magnesium in drinking water and risk of death from rectal hypertension. American Journal of Hypertension, 12, 894-899.

Yang, C. Y., Chiu, H. F., Chang, C., Wu, T. N., \& Sung, F. C. (2002). Association of very low birth weight with calcium levels in drinking water. Environmental Research Section A, 89, 189-194. 